\title{
«Villa Sult» - et uklokt navnevalg
}

«Villa Sult» er navnet på et nytt institutt for spiseforstyrrelser i Oslo. Jeg synes det er et useriøst og respektløst navn.

I en reportasje i Morgenbladet i sommer omtales psykiater Finn Skårderuds nye institutt for spiseforstyrrelser (1). Det skal romme terapi, forskning og kultur. Som Skårderud beskriver, er anorexia nervosa en alvorlig sykdom med relativt høy dødelighet og mye lidelse. Den forstyrrer en ungdoms kognitive og psykologiske utvikling på en gjennomgripende negativ måte. Fysisk helse påvirkes med livslange konsekvenser.

I dette perspektivet synes jeg det er useriøst og respektløst nærmest å estetisere sykdommen ved å kalle en behandlingsinstitusjon for «Sult» med referanse til stor litteratur. Finn Skårderud engasjerer seg også i kulturelle temaer, men i en behandlingsinstitusjon bør man skille mellom kunstuttrykk og sykdom. Her skal oppmerksomheten være rettet mot pasientens perspektiv. Jeg synes Skårderud mister dette perspektivet ved navnevalget. Tenk på tilsvarende navn: «Villa Kreft», «Villa Rusavhengig» eller «Villa Angst», så forstår man det usmakelige i navnevalget. Jeg frykter at navnevalget og den kunstneriske tilnærmingen kan føre til en sementering av sykdomsprosessen hos enkelte pasienter: personen med anoreksi og kunstneren finner felles klangbunn $\mathrm{i}$ «Villa sult»: «der har jeg min identitet.»

I avisreportasjen stiller journalisten mange gode spørsmål, blant annet om synet på kognitiv terapi. Sterke fagmiljøer hevder at for anoreksipasienter er vektøkning gjen- nom kognitiv terapi en forutsetning for at en mer langsiktig psykodynamisk tilnærming skal ha noen hensikt. I et nyetablert institutt for behandling av spiseforstyrrelser synes jeg det er betenkelig at ikke kognitiv terapi tas inn som en del av behandlingstilbudet når nyere forskning viser gode resultater. Det refereres til danske psykiatere som ut fra egne erfaringer tviler på nytten av psykodynamisk tilnærming til disse pasientene. Jeg synes Skårderud avdekker

\section{«Både navnevalg og beskrivelse av faglig tilnærming er lite tillitvekkende»}

en arrogant holdning til andres forskningsresultater når han hevder at det bare er egen form for psykodynamisk psykoterapi som duger og at negative resultater med denne type behandling fra andre behandlingsmiljøer er irrelevante. Helhetstenkning burde prege et nytt institutt. Menneskesinnet er sammensatt og må møtes med sammensatt behandling.

Sett med pårørendes øyne synes jeg derfor både navnevalg og beskrivelse av faglig tilnærming er lite tillitvekkende, særlig fordi dette fremmes av en av landets toneangivende fagpersoner på området. Det er på høy tid at Helse- og omsorgsdepartementet făr fortgang i prosessen med å utarbeide nasjonale faglige retningslinjer for utredning og behandling av spiseforstyrrelser. Da vil barnet forhåpentligvis slippe å bli kasteball mellom ulike fagmiljøer, der noen sverger til kunstterapi, yoga og velment prat, andre til psykodynamisk tilnærming og atter andre til kognitiv terapi. Barneog ungdomssinnet har ikke tid til å teste ut alt dette, og familiene har ofte ikke styrke til å tåle alle nederlagene.

\section{Kathinka Aslaksen \\ kathinka.aslaksen@gmail.com}

Kathinka Aslaksen (f. 1957) er spesialist i barnesykdommer ved Sørlandet sykehus. Forfatter har fylt ut ICMJE-skjemaet og oppgir ingen interessekonflikter.

\footnotetext{
Litteratur

1. Olsen MN. En villa ved navn Sult. Morgenbladet 31.7.2014. http: //morgenbladet.no/samfunn/2014/ en_villa_ved_navn_sult (15.8.2014).
}

Mottatt 14.8. 2014 og godkjent 17.8. 2014. Redaktør: Erlend Hem.

Publisert først på nett. 